\title{
MEDIASTINAL AND PULMONARY ENTOMOPHTHOROMYCOSIS WITH SUPERIOR VENA CAVA SYNDROME: CASE REPORT
}

\begin{abstract}
SUMMARY
The first case of mediastinal and pulmonary entomophthoromycosis with supe rior vena cava syndrome is reported. The patient presented with a history of edema of the face, neck and upper limbs as well as collateral circulation in the anterior wall of the chest. Histological examination of tissue from mediastinum revealed a granulomatous reaction with microabscesses surrounded by eosinophilic amorphous material and with broad hyphae in the center. Culture was not performed because a preliminary diagnosis of non Hodgkin's malignant lymphoma was made. Surgical correction of the obstructed area was performed and the patient was sucess fully treated with potassium iodide. The authors propose that mediastinal entomoph thoromycosis must be considered in the differential diagnosis of diseases causing superior vena cava syndrome in tropical and sub tropical regions. This case enlarges the spectrum of clinical manifestations of the zigomycosis caused by Entomoph. thoraceae.
\end{abstract}

KEY WORDS: Mediastinal and pulmonary entomophthoromycosis; Superior vena cava syndrome.

\section{INTRODUCTION}

Zygomycosis is a collective designation of the mycotic infections caused by several species of Zygomycetes, orders Mucorales and Entomophthorales ${ }^{3.6 .9}$. Zygomycosis is characterized by the presence of broad ( $5 \cdot 20 \mu \mathrm{m}$ in width), occa sionally septate, and aberrantly ramified hyphae in the host's tissue ${ }^{1.2 .}$. It is possible to distin guish the hyphae of Mucorales from those of the Entomophthorales in tissue sections stained by $H E$ : the hyphae of Mucorales are clearly seen because they have a well stained cell wall; those of Entomophthorales are sleeved by eosinophi lic material (Splendore-Hoeppli phenomenon) ${ }^{3}$ 6. 9

Zygomycosis caused by species of Entomophthorales has a chronic course and affects apparently healthy hosts in tropical or subtropical regions. Its subcutaneous form? " caused by Basidiobolus ranarum ( = haptosporus or

\footnotetext{
1: Departamento de Patologia. Instituto Brasileiro para Investigaçao do Torax - Fundacao Jose Silveira. Salvador. Bahia Brazil. Professor Titular de Anatomia Patologica. Fundacan Bahiana para Desenvolvimentoda Medieina Eseola de Medicina e Saude Publica, Salvador. Bahia, Brazil

(2) Professor Assistente de Pneumologia da Faculdade de Medicina da Universidade Federal da Bahia. Salvador. Bahia. Brazil (3) Protessor Titular de Cirurgia Toraxica da Faculdade de Medicina da Universidade Federal da Bahia. Salvador. Bahia. Brazil 
COELHO FILHO. J. C.; PEREIRA. J. \& RABELLO JUNIOR A - Mediastinal and pumonary entomophthormarosi. with superior vena cava syndrome case report Rev. Inst. Med. trop. S. Paulo, 31 16 \%: 430 433. 1989

Conidiobolus coronatus is more frequent. Howe ver cases of disseminated or primary localized visceral involvement have also been reported ${ }^{3}$ 8. 10. Exclusive thoracic involvement was descri bed only once ${ }^{10}$. The purpose of this paper is to report a case of zygomycosis caused by an Entomophthoraceae involving the lung and the me diastinum and causing a superior vena cava syn drome (SVCS)

\section{CASE REPORT}

A 29 years-old woman from Salvador, Bahia, Brazil, was admitted in July 1984 with a recent history of edema of the face, neck and upper limbs as well as collateral circulation in the ante rior wall of the chest. Urinalysis, hemogram, blood sugar, urea and nitrogen were within nor mal limits. Eletrocardiogram showed no abno malities. An X-ray of the chest and a computerized tomography revealed a small nodule on the upper lobe of the right lung and an enlarge ment of the middle and superior mediastinum especially near the azigos vein (Fig. 1). The cavo graphy revealed invasion and obstruction of the superior vena cava with evidence of collateral circulation (Fig. 2 ). A clinical diagnosis of non Hodgkin's malignant lymphoma with SVCS was made. Exploratory thoracotomy showed a gra nular and friable tissue involving the wall of the superior vena cava and other mediastinal veins. A biopsy was obtained and surgical correction of the obstructed area performed.

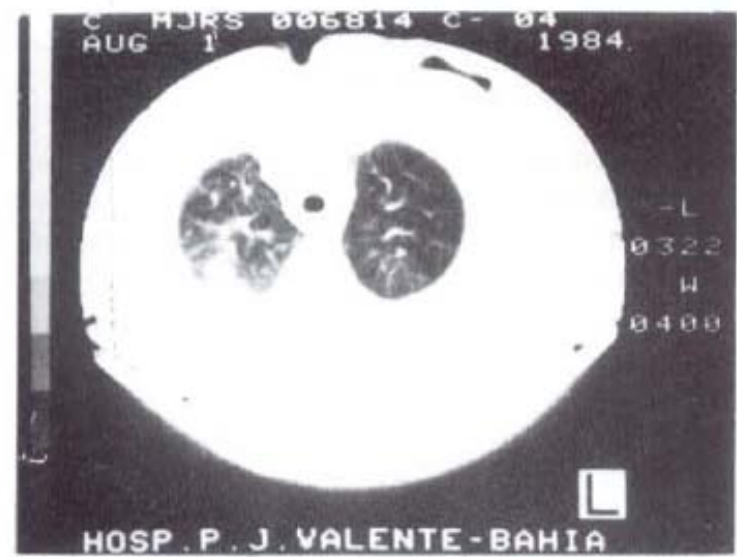

Fig. 1 - Computarized tomography showing small nodule in the right hemithorax.

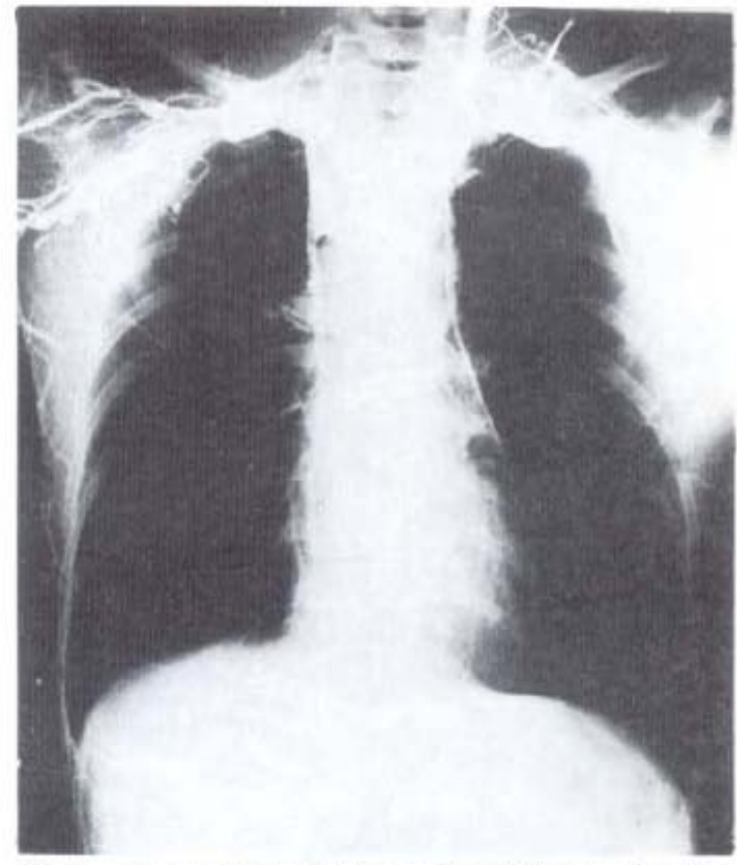

Fig. 2 - Cavography with obstruction of the superior vena cava and showing collateral circulation.

\section{PATHOLOGIC FINDINGS}

Histological sections stained by HE revealed a chronic granulomatous reaction. Small absces ses with neutrophils and eosinophils surrounded by histiocytes and multinucleated giant cells we re also observed. Broad hyphae $(10 \mu \mathrm{m}$ in diame ter) were seen inside the microabscesses. The hyphae, occasionally septate were sleeved by and eosinophilic material (Splendore-Hoeppli phenomenon) (Fig. 4). This reaction was also well observed in P. A. S. stained sections. The hyphae were well impregnated by silver (Grocott's me thod) (Fig. 5).

Following histopathological diagnosis im munological evaluation was made. Intradermal skin tests with PPD. Candidin and Trichophtin and the determination of population and sub po pulations of lymphocytes showed no abnorma lities (Lymphocytes $\mathrm{T}-69 \%$; OKTA $=50 \%$; OKT8 $=19 \% ;$ lymphocytes $\mathrm{B}=15 \% ; \mathrm{mixed}$ lymphocytes $=16 \%$. The patient was success fully treated with potassium iodide $(20 \mathrm{mg} / \mathrm{kg}$ day during 6 months). No relapse was observed in a 20 months follow up. 
COFLHO FILHO. J. C.; PEREIRA, J. \& RABELLO JUNIOR, A. - Mediastinal and pulmonary entomophthoromycosis with superior vena cava syndrome: case report. Rev. Inst. Med. trop. S. Paulo, 31(6): 430 433, 1989

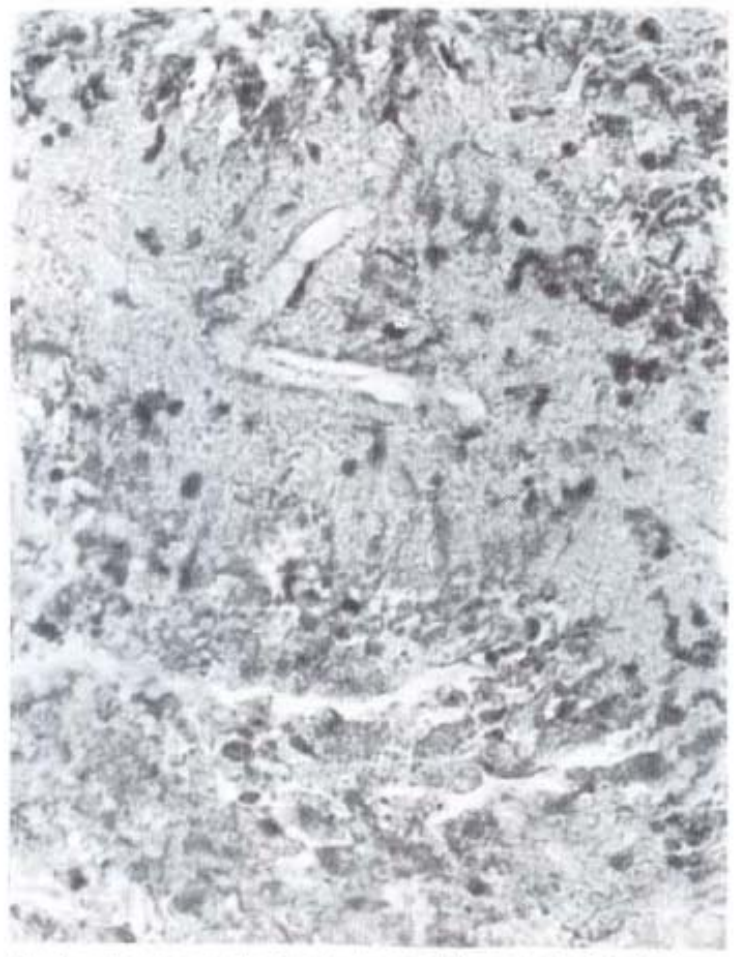

Fig. 3-Hyphae coated with eosinophilic material (Splendore. Hoeppli phenomenon) $\mathrm{HE}(\mathrm{X} 400)$.

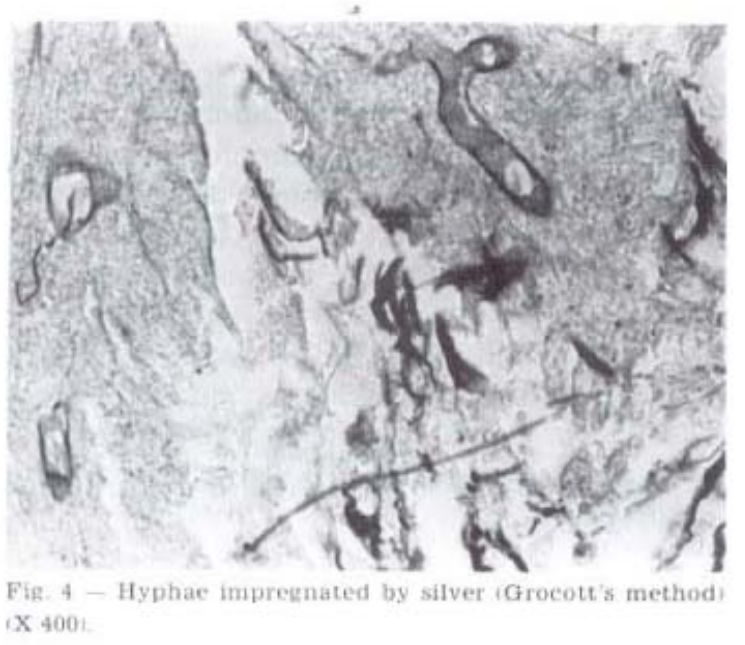

\section{DISCUSSION}

This case represents the second of primary intrathoracic Entomophthoromycosis and the first manifested as SVCS. The first was described by ECKERT ${ }^{10}$ and was caused by $\mathbf{C}$. incongruus. In the case of BUSAPAKUM et $\mathrm{al}^{8}$, there were lesions in the lungs, liver, digestive tract and skin, but there is doubt if the lungs were the primary site of disease. Another case of Entomophthoromycosis with pulmonary involvement was se condary to a skin lesion in the chest ${ }^{7}$. Although. the etiological agent was not isolated in the pre sent case the histopathological aspects permit the diagnosis of Entomophthoromycosis, due to the presence of a granulomatous process with an eosinophilic infiltrate and the Hoeppli-splendore phenomenon. Mucormycosis is also a zygo mycosis that causes visceral lesions but it mani fests itself with a different histopathological pattern $^{5 .}{ }^{1 "}$; moreover, it occurs only in immunosupressed patients ${ }^{12}$.

The SVCS results usually from the involve ment of the mediastinum by malignant pulmo nary tumors, lymphomas and, less frequently, by inflammatory processes like tuberculosis and histoplasmosis ${ }^{11}$. In the case reported the mycotic origin of the syndrome was strongly sugges ted by its disappearance with the specific treat ment. Certainly, the pulmonary lesion was pri mary, with posterior propagation to the mediastinum.

We propose that mediastinal Entomoph thoromycosis must be considered in the differential diagnosis of diseases causing SVCS in tropical and subtropical regions. On the other hand, this case enlarges the spectrum of cliniral manifes tation of the zygomycosis caused by Entomophthoraceae.

\section{RESUMO}

Entomoftoromicose mediastinal e pulmonar com síndrome de veia cava superior: registro de caso.

O primeiro caso de entomoftoromicose mediastinal e pulmonar com sindorme de veia cava superior, é descrito. A paciente apresentou-se com história de edema facial, cervical e de mem bros superiores, bem como circulaçāo colateral na parede anterior do tórax. O estudo histopatológico do tecido do mediastino, próximo à veia cava, revelou reação granulomatosa com microabscessos, circundados por material amorfo, eosinofilico e com hifas largas no centro. Cultura não foi realizada porque o diagnóstico clínico foi de doença de Hodgkin ou de um linfoma nāo- 
COELHO FILHO. J. C.: PEREIRA. J. \& RABELLO JUNIOR. A. - Mediastinal and pulmonary entomophthommeosis with superior vena cava syndrome: case report. Rev. Inst. Med. trop. S. Paulo, 3161:430 433. 1989

Hodgkin. Correção cirúrgica da área obstruída foi realizada e a paciente tratada com iodeto de potássio, nas doses preconizadas, obtendo-se sucesso. Os autores propōem que a entomoftoro micose mediastinal deva ser considerada no diagnóstico diferencial de doença causando síndrome de veia cava superior em regioes tropicais e sub-tropicais. Este caso aumenta o espectrum de manifestaçōes clínicas das zigomicoses cau sadas por Entomophthoraceae.

\section{ACKNOWLEDGMENTS}

We gratefully acknowledge Dr. A Bittencourt (Universidade Federal da Bahia) and Dr. A. T Londero (Universidade Federal de Santa Maria$R S$ ) for their critical review of this paper.

\section{REFERENCES}

1. AGUiAR. E.: MORAIS. W. C. \& LONDERO, A. T. - Gas trointestinal entomophthoromycosis caused by Basidio bolus haptosporus. Mycopathologia (Den Haag), i2 $101-105,1980$.

2. ANDRADE, Z. A. \& ANDRADE, S. G. - A entomoftoro micose nasal. Rev. Soc. bras. Med. trop., 6: 239-249.1972

3. BITTENCOURT, A. L. -- Entomoftoromicoses - Revisāo Med. cut. ibero lat-amer., 16: 93100,1988

4. BITTENCOURT A. L. ARAUJO, M. G. S. \& PAES, M. S. F. - Occurrence of subcutaneous zygomycosis lento mophthoromycosis basidiobolaercaused by Basidiobolus haptosporus with pulmonary involvement. Myeopathologia (Den Haag), il: 155:158, 1980.

5. BITTENCOURT. A. L.: AYALA. M. A. R. \& RAMOS. E A. G. - A new form of abdominal zygomycosis differm from mucormycosis. Report of two cases and levien of the literature. Amer. J. trop. Med. Hyg., 28: 564-569.1979

6. BITTENCOURT. A. L.: QUEIROZ, A. C.: COELHO FI LHO. J. C.: BARRETO. E.: COSTA. I. M.: COUTO. M S. \& COSTA. M. R. - Rinoentomoftoromicose. Apresen taçāo de quatro casos. Med. cut. ibero. lat-amer, 11 177182.1983

7. BITTENCOURT. A. L.: SERRA. G.: SADIGURSKY. M. ARAUJO, M. G. S. CAMPOS, M C. S. \& SAMPAIO. I C. M. - Subeutaneous zygomycosis caused by Basidiobolus haptosporus: presentation of a case mimicking Bur kitt's lymphoma. Amer. J. trop. Med. Hyg., 31: 370373. 1982

8. BUSAPAKUM, R: YOUNGCHAIYUD, U : SRIUMPAI S.: SEGRETAIN, G. \& FROMENTIN, H. ... Disscminated infection with Conidiobolus incongruus. Sabouraudia, 21: 323330,1983

9. CAMENON H. M. GATEI. L. \& BREMNER, A. D. - The deep mycosis in Kenia: a histopathological study. 2. Phy comycosis. E. Afr, med. J., 50: $396405,1973$.

10. ECKERT, H. L.: KHOURY, G. H.: PORE, R, S.: GIL BERT. E. F. \& GASKELL, J.R. - Deep Entomophthora phycomycotic infection reported for the first time in the United States. Chest, 61: 392.394. 1972.

11. RODRIGUES, N. \& STRAUS.M. I. - Superiorvena caval syndrome in lung cancer. New York. Grune \& Strattor. 1983. p.323-333.

12. SYMMERS. W. S. C. - Histopathology of phycomycosis Ann. Soc. Belge Med. trop., 52: 365 388. 1972.

Recebido para publicação em 13041989 